\title{
The Relationship between Capital Structure and Financial Performance in the Companies Listed in Abu Dhabi Securities Exchange: Evidences from United Arab Emirates
}

\author{
Anas Ali Al-Qudah ${ }^{1}$ \\ ${ }^{1}$ Emirates College of Technology, Abu Dhabi, UAE \\ Correspondence: Anas Ali Al-Qudah, Emirates College of Technology, ECT, Abu Dhabi, Banking and Finance \\ Department, Millennium Tower, Sheikh Hamdan Street, P. O. Box: 41009, Abu Dhabi, United Arab Emirates. \\ E-mail: anas.alqudah@ect.ac.ae
}

Received: January 23, 2017

Accepted: February 3, 2017

Online Published: March 2, 2017

doi:10.5539/res.v9n2p1

URL: http://doi.org/10.5539/res.v9n2p1

\begin{abstract}
This study aimed to examine the relationship between capital structure and financial performance in the firms listed in Abu Dhabi Securities Exchange (ADX), Profitability Ratios were used to express of the financial performance, and the Debt Ratio was used to express the Capital Structure. A random sample from the companies listed in ADX was taken to achieve the objective this study, it consisted of $48 \%$ of all companies in this financial market, and the study period extended from 2008 to 2015. The researcher used Statistical Package for the Social Sciences (SPSS), to analyze the study hypotheses, using ANOVA, model summery and coefficients for the study variables. And the results of this study showed that is positive relationship between the capital structure (Debt Ratio) and the Financial Performance (Profitability: Return on Assets) in ADX. And there is a negative relationship when we used the Return on Equity to express for the Profitability with the capital structure. The overall study results showed that there is significant relationship between capital structure and financial Performance in the companies listed in Abu Dhabi Securities Exchange, and the model of this study able to explanation almost $31 \%$ from changes happened in the profitability due to the capital structure. This result was consistent with some previous studies.
\end{abstract}

JEL classification: G20, G21, G24, G30, G31

Keywords: Abu Dhabi securities Exchange (ADX), Return on Assets (ROA), Return on Equity (ROE), Debt Ratio (DR), profitability, capital structure, financial performance

\section{Introduction}

The relationship between Capital Structure and financial performance in the firms is an important unsolved issue in the field of finance and it has been investigated extensively both theoretically and empirically. There are four different theories about capital structure which reflect the effect of debt on profitability performance: Pecking order theory, the agency costs theory, tradeoff theory, and signaling theory. Most of them demonstrated that firm performance can be affected by capital structure decisions. For determining the optimal capital structure, these modern theories take into account taxes and financial distress costs.

The pioneer works about the role of the debt is Modigliani and Miller's (1958). They confirm that the owners of the firms are indifferent about its capital structure, because the value of the firm does not change with a change in leverage. In other words, their idea is that firm's value is maximized when it uses more of debt in its capital structure than equity. If debt is employed in the capital structure, the average cost of capital is reduced and profitability improved. Lately, a new proof was presented by Modigliani and Miller (1963) showing that the value of a firm increases with more debt due to the tax shied.

Most of empirical studies reveal a mix results and can be divided into two views. The first view finds a positive relationship between profitability in firm and debt (Dessi \& Robertson, 2003; Goddard et al., 2005; Weill, 2008; Margritis \& Psillaki, 2010; Kebewar, 2012). They confirmed the agency cost theory that affirms higher leverage is associated with better firm performance. In addition, Margritis and Psillaki (2010) explained this result to that low growth firms attempt to depend on the borrowing for utilizing the expected growth opportunities and investing borrowing money at the profitable projects, therefore it will increase the firm performance. 
The second view finds a negative correlation between debt level and firm performance (Nassar, 2016; Chuke et al., 2016; Darush \& Peter, 2015; Vatavu, 2014; Chandrapala \& Knapkova, 2013; Iorpev \& Kwanum, 2012). These authors used a different methodology. For example, Darush and Peter (2015) use three-stage least squares (3SLS) and fixed-effects models to analyze a comprehensive, cross-sectoral sample of 15,897 Swedish SMEs operating in five industry sectors during the 2009-2012 period. They confirm that debt ratios, in terms of trade credit, short-term debt and long-term debt, negatively affect firm performance in terms of profitability. As a high debt ratio seems to increase the agency costs and the risk of losing control of the firm, SME owners and managers tend to finance their businesses with equity capital to a fairly high degree. In the same way, Abor (2005) revealed a negative impact of long term debt on firm performance due to the high interest rate.

\section{Literature Review}

All over the world studies have been conducted to detect the relationship between Capital Structure and Financial Performance, through a review of previous literature the researcher tried to begin from the eighties until this decade of this century, where they found several studies that dealt with the same subject.

Baum et al. (2006) examined a sample of companies in German industrial firms to detect the variables above between 1988 to 2000, they were used GMM estimation, and the result of this study was firms are more profitable when they rely more heavily on short term liabilities. Magaritis and Psillaki (2010) examined a sample of companies in French manufacturing firms between 2002 to 2005, they were used DEA analysis, and the result of this study was higher leverage associated with higher efficiency.

Valeriu and Nimalathasan (2010) examined a sample of listed manufacturing companies in Sri Lanka 2003-2007, they were used simple regression model, and the result of this study was debt is positively and strongly associated to all profitability ratios. Iorpev and Kwanum (2012) examined a sample of manufacturing companies in Nigeria 2005-2009, they were used Multiple regression analysis, and the result of this study was Negative and insignificant relationship between debt (Short and Long term to total assets) and ROA and profit margin; Positive relationship between ROE and debt. Kebewar (2013) examined a sample of French services firms 1999-2006 they were used GMM estimation, and the result of this study was no correlation between debt ratio and profitability ratios.

Chandrapala and Knapkova (2013) examined a sample of Czech firms 2004-2008 they were used Panel data: Fixed effect model, and the result of this study was Negative relationship between leverage and profitability. Vatavu (2014) examined a sample of Romanian listed firms 2003-2012, they were used GMM estimation, and the result of this study was Negative relationship between leverage and profitability. Darush and Peter (2015) examined a of Swedish SMEs firm 2009-2012 they were used Three-stage least squares (3SLS) and fixed-effects models, and the result of this study was Negative relationship between debt ratios (short-term debt and long-term debt) and firm performance (profitability ratios).

Chuke et al. (2016) examined a sample of Nigeria listed firms 2001-2012, they were used Fixed Effects and Random Effects, and the result of this study was Negative and significant impact owing to limited long term debt. Nassar (2016) examined a sample of Industrial companies in Turkey 2005-2012, he was used Multivariate regression analysis and the result of this study was a Negative significant relationship between capital structure and firm performance.

The Table 1 below shows the results of the most studies that conducted on the relationship between the capital structure and the financial performance, the results showed a varied output extend between Negative, Positive, and No correlation between these variables.

Table 1. Review of the empirical literature

\begin{tabular}{ccccl}
\hline Authors & Sample & Analysis Period & Methodology & \multicolumn{1}{c}{ Results } \\
\hline Baum et al. (2006) & $\begin{array}{c}\text { German industrial } \\
\text { firms }\end{array}$ & 1988-2000 & GMM estimation & $\begin{array}{l}\text { Firms are more profitable when they rely } \\
\text { more weightily on short term liabilities. } \\
\text { Magaritis and } \\
\text { Psillaki (2010) }\end{array}$ \\
\hline
\end{tabular}




\begin{tabular}{|c|c|c|c|c|}
\hline $\begin{array}{l}\text { Valeriu and } \\
\text { Nimalathasan } \\
\text { (2010) }\end{array}$ & $\begin{array}{c}\text { Listed } \\
\text { manufacturing } \\
\text { companies in Sri } \\
\text { Lanka }\end{array}$ & $2003-2007$ & $\begin{array}{l}\text { Simple } \\
\text { regression model }\end{array}$ & $\begin{array}{l}\text { Debt is positively and strongly associated to } \\
\text { all profitability ratios. }\end{array}$ \\
\hline $\begin{array}{l}\text { Iorpev and Kwanum } \\
\qquad(2012)\end{array}$ & $\begin{array}{l}\text { Manufacturing } \\
\text { companies in } \\
\text { Nigeria }\end{array}$ & 2005-2009 & $\begin{array}{l}\text { Multiple } \\
\text { regression } \\
\text { analysis }\end{array}$ & $\begin{array}{l}\text { Negative and insignificant relationship } \\
\text { between debt (Short and Long term to total } \\
\text { assets) and ROA and profit margin; } \\
\text { Positive relationship between ROE and debt. }\end{array}$ \\
\hline Kebewar (2013) & $\begin{array}{l}\text { French services } \\
\text { firms }\end{array}$ & 1999-2006 & GMM estimation & $\begin{array}{l}\text { No correlation between debt ratio and } \\
\text { profitability ratios. }\end{array}$ \\
\hline $\begin{array}{l}\text { Chandrapala and } \\
\text { Knapkova (2013) }\end{array}$ & Czech firms & 2004-2008 & $\begin{array}{l}\text { Panel data: Fixed } \\
\text { effect model }\end{array}$ & $\begin{array}{l}\text { Negative relationship between leverage and } \\
\text { profitability. }\end{array}$ \\
\hline Vatavu (2014) & $\begin{array}{l}\text { Romanian listed } \\
\text { firm }\end{array}$ & 2003-2012 & GMM estimation & $\begin{array}{l}\text { Negative relationship between leverage and } \\
\text { profitability. }\end{array}$ \\
\hline $\begin{array}{l}\text { Darush and Peter } \\
\qquad(2015)\end{array}$ & Swedish SMEs & 2009-2012 & $\begin{array}{l}\text { Three-stage least } \\
\text { squares (3SLS) } \\
\text { and fixed-effects } \\
\text { models }\end{array}$ & $\begin{array}{l}\text { Negative relationship between debt ratios } \\
\text { (short-term debt and long-term debt) and } \\
\text { firm performance (profitability ratios). }\end{array}$ \\
\hline $\begin{array}{l}\text { Chuke and all } \\
\qquad(2016)\end{array}$ & Nigeria listed firms & 2001-2012 & $\begin{array}{c}\text { Pooled OLS, } \\
\text { Fixed Effects and } \\
\text { Random Effects }\end{array}$ & $\begin{array}{l}\text { Negative and significant impact owing to } \\
\text { limited long term debt. }\end{array}$ \\
\hline Nassar (2016) & $\begin{array}{l}\text { Industrial } \\
\text { companies in } \\
\text { Turkey }\end{array}$ & 2005-2012 & $\begin{array}{l}\text { Multivariate } \\
\text { regression } \\
\text { analysis }\end{array}$ & $\begin{array}{l}\text { Negative significant relationship between } \\
\text { capital structure and firm performance. }\end{array}$ \\
\hline
\end{tabular}

Source: maid by researcher.

\section{The Study Objective}

Abu Dhabi Securities Exchange (ADX) is emerging market between the financial markets in the Arab region, it follows the United Arab Emirates economics, and this study came to address two main variables in this regard, the researcher believe that it's very important to discover the nature of relationship between the capital structure and the financial performance in this market. Where the researcher expressed by the Debt ratio for the capital structure, and by the profitability ratios for the financial performance, in order to discover the financial performance efficiency in light of the existence of the debt in the capital structure.

\section{The Population \& the Sample of the Study}

\subsection{The Study Population}

The population of this study is the companies listed in Abu Dhabi Securities exchange, this financial market was established in November 15, 2000 for trading shares and bonds of local and foreign companies.

\subsection{The Study Sample}

The sample of this study includes random companies taken from listed companies in Abu Dhabi Securities exchange. There are many sectors in the Abu Dhabi Securities Exchange (ADX). But it consider a small number companies in this financial market compared to other markets, so the researcher take approximately $48 \%$ as random sample from the a whole companies listed in (ADX). The Table 2 below includes the study sample. 
Table 2. The study sample

\begin{tabular}{cccl}
\hline SR & Sector & Symbol & \multicolumn{1}{c}{ Company } \\
\hline 1 & Services & ADAVIATION & Abu Dhabi Aviation Co. \\
2 & Insurance & ABNIC & Al Buhaira National Insurance \\
3 & Services & ADNH & Abu Dhabi National Hotels \\
4 & Insurance & ADNIC & Abu Dhabi National Insurance Co. \\
5 & Industrial & ADSB & Abu Dhabi Ship Building PJSC \\
6 & Consumer Staples & AGTHIA & AGTHIA GROUP PJSC \\
7 & Banks & ADCB & Abu Dhabi Commercial Bank \\
8 & Banks & ADIB & Abu Dhabi Islamic Bank
\end{tabular}

Source: made by researcher.

\section{The Study Method}

The researcher will use the Statistical Package for the Social Sciences (SPSS) in order to achieve the objective of this study; they found it the most appropriate way for this type of research. In order to examine the relationship between debt level and firm performance for firms listed on Abu Dhabi Stock Exchange (ADX), we should choose the indicators of performance at the level of firm because it is measured in many ways. According Ittner (2008), firm performance could either be financial and non-financial performance. The non-financial indicators can be used as a performance measurement for companies: customer satisfaction, product or service quality, market shares and employee efficiency. The financial indicator is a subjective measure and is used as a general measure of profitability and cash flow position, using firm's overall financial sheet.

In this paper, we focus on the financial performance (profitability ratios) because the advantage of these measurements is their general availability. The ratios that will be used include Return On Assets (ROA) and Return On Equity (ROE) and Debt Ratio (DR). So the researcher need to collect the published financial statements for the companies listed in ADX, especially the income statements and the balance sheets.

Below the steps that the researcher goes through it in the next sections.

\subsection{The First Step}

Collect the historical financial statements from the secondary resources of data, which published by the Abu Dhabi Security Exchange (ADX), these annually data collected for the study sample that includes eight companies listed in ADX for the period (2008-2015).

\subsection{The Second Step}

Calculate the Return On Assets (ROA), Return On Equity (ROE) and Debt Ratio (DR) from the data inserted in the income statements and the balance sheets.

\subsection{The Third Step}

Organize the information calculated annually to make each year includes the Return On Assets (ROA), Return On Equity (ROE) and Debt Ratio (DR) in an orderly manner using Microsoft Office Excel software.

\subsection{The Fourth Step}

Insertion the data collected from Microsoft Office Excel software to the Statistical Package for the Social Sciences (SPSS).

\subsection{The Fifth Step}

Using the Correlations, Model Summary, ANOVA, and Coefficients which result from SPSS to test the study hypothesis.

\subsection{The Sixth Step}

The researcher will use the output in the previous steps to conclude the results and attempt to recommend to companies in ADX on ways to manage their debt levels within the capital structure. 


\section{The Study Model}

This study aims to discover of the relationships between the relationship between the capital structure and the financial performance in the Abu Dhabi Securities Exchange (ADX), so the researcher put the following virtual model to clarification this relationship.

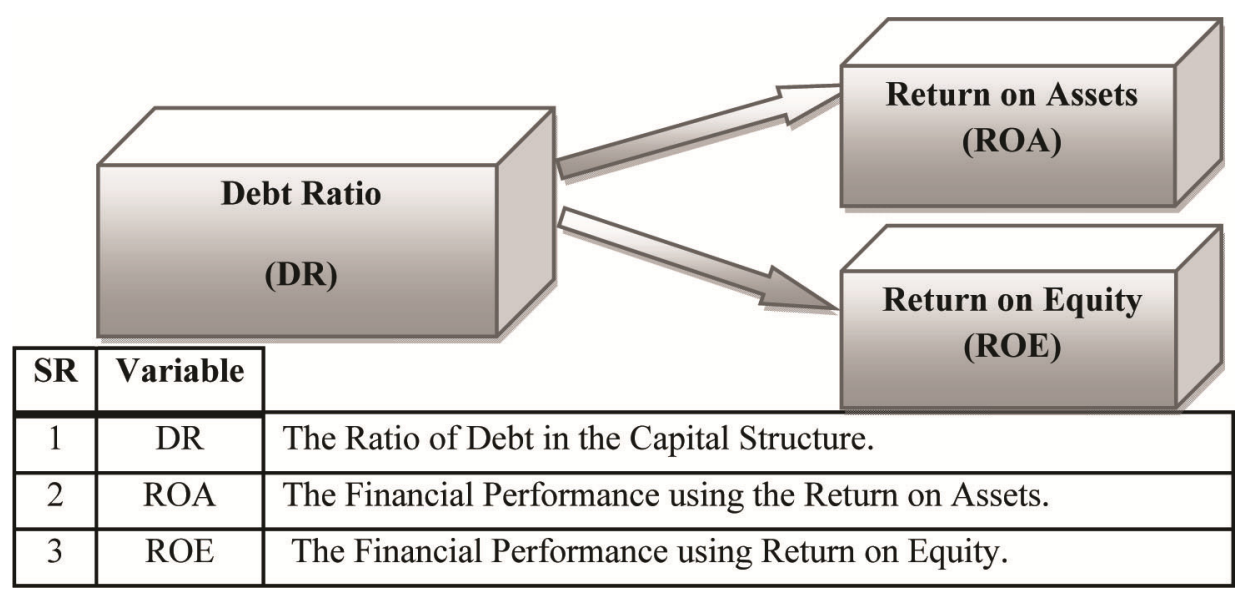

Figure 1. The Virtual Model of the study

According to the study model above the researches derive the Mathematical model in order to measure the relationships between the capital structure and the financial performance in the Abu Dhabi Securities Exchange (ADX), the equation (1) below shows the model which was adopted by the researcher to build the study hypotheses:

$$
D R_{i t}=\alpha+\beta_{1} * R O A_{i t}+\beta_{2} * R O E_{i t}+\bar{e}
$$

Where,

$\mathrm{ROA}_{\mathrm{it}}$ : Return on Assets for the Company (i) for the Period ( $\mathrm{t}$ )

$\mathrm{ROE}_{\mathrm{it}}$ : Return on Equity for the Company (i) for the Period ( $t$ )

$\mathrm{DR}_{\mathrm{it}}$ : The Annual Return for the Company (i) for the Period ( $\mathrm{t}$ )

é: Random Error

\section{The Study Hypotheses}

According to the Mathematical model in the equation (1) the researcher puts the following hypotheses.

\subsection{The Main Hypothesis}

H1: The significant relationship between the capital structure (DR) and the Financial Performance (ROA, ROE) in the companies listed in the Abu Dhabi Securities Exchange (ADX) for the period (2008-2015).

H0: There is no significant relationship between the capital structure (DR) and the Financial Performance (ROA, ROE) in the companies listed in the Abu Dhabi Securities Exchange (ADX) for the period (2008-2015).

\subsection{The 1st Sub-Hypothesis}

H1a: There is significant relationship between the capital structure (DR) and the Financial Performance (ROA) in the companies listed in the Abu Dhabi Securities Exchange (ADX) for the period (2008-2015).

H0a: There is no significant relationship between the capital structure (DR) and the Financial Performance (ROA) in the companies listed in the Abu Dhabi Securities Exchange (ADX) for the period (2008-2015).

\subsection{The 2nd Sub-Hypothesis}

H1b: There is significant relationship between the capital structure (DR) and the Financial Performance (ROE) in the companies listed in the Abu Dhabi Securities Exchange (ADX) for the period (2008-2015).

H0b: There is no significant relationship between the capital structure (DR) and the Financial Performance (ROE) in the companies listed in the Abu Dhabi Securities Exchange (ADX) for the period (2008-2015). 


\section{The Study Variables}

The Main three variables used by the researches to test the capital structure and the financial performance were the following.

\subsection{Independent Variables (Financial Performance): Profitability Ratios}

$$
\boldsymbol{R O} A_{i t}=N . I_{i t} \div T . A_{i t}
$$

Where,

N.I $\mathrm{I}_{\mathrm{it}}$ : Net Income for the Company (i) for the Period (t)

T. $\mathrm{A}_{\mathrm{it}}$ : Total Assets for the Company (i) for the Period ( $\mathrm{t}$ )

ROA: Return on Assets for the Company (i) for the Period (t)

$$
R O E_{i t}=N . I_{i t} \div T . E_{i t}
$$

Where,

N.I $\mathrm{I}_{\mathrm{it}}$ : Net Income for the Company (i) for the Period (t)

T. $E_{\mathrm{it}}$ : Total Equity for the Company (i) for the Period ( $\mathrm{t}$ )

ROE: Return on Equity for the Company (i) for the Period (t)

8.2 Dependent Variable (Capital Structure): Debt Ratio

$$
D . R=L R D_{i t} \div T . A_{i t}
$$

Where,

LRD $_{\text {it }}$ : Long Run Debt for the Company (i) for the Period ( $t$ )

T.A $\mathrm{A}_{\mathrm{it}}$ : Total Assets for the Company (i) for the Period ( $\mathrm{t}$ )

D.R: Debt Ratio for the Company (i) for the Period ( $t$ )

\section{Analyzing Data \& the Study Results}

For the purpose of testing hypotheses the researcher used SPSS output (Model Summary, ANOVA, and Coefficients), to examine the relationship between the capital structure and the Financial Performance in ADX.

\begin{tabular}{|c|c|c|c|c|}
\hline & & DR & ROE & ROA \\
\hline \multirow{3}{*}{ DR } & Pearson Correlation & 1 & $0.051^{* *}$ & $0.069^{*}$ \\
\hline & Sig. (2-tailed) & & 0.011 & 0.038 \\
\hline & $\mathrm{N}$ & 64 & 64 & 64 \\
\hline \multirow{3}{*}{ ROE } & Pearson Correlation & $0.051^{* *}$ & 1 & $.093^{* *}$ \\
\hline & Sig. (2-tailed) & 0.011 & & .000 \\
\hline & $\mathrm{N}$ & 64 & 64 & 64 \\
\hline \multirow{3}{*}{ ROA } & Pearson Correlation & $0.069^{*}$ & $0.093^{* *}$ & 1 \\
\hline & Sig. (2-tailed) & .038 & .000 & \\
\hline & $\mathrm{N}$ & 64 & 64 & 64 \\
\hline
\end{tabular}

The following table shows the Correlations between the study variables.

Table 3. Correlations

**Correlation is significant at the 0.01 level (2-tailed).

*Correlation is significant at the 0.05 level (2-tailed).

As Table 3 above shows the correlations among study variables were less than 0.8 , so there is no of Multicollinearity problem.

The following table shows the Model Summary for the study Model. 
Table 4. Model Summary

\begin{tabular}{ccccc}
\hline Model & $\mathrm{R}$ & $\mathrm{R}^{2}$ & Adjusted $\mathrm{R}^{2}$ & Std. Error \\
\hline 1 & $0.556^{\mathrm{a}}$ & 0.309 & 0.267 & 0.12334 \\
\hline
\end{tabular}

a. Predictors: Constant, ROA, ROE.

As the table above shows, $\mathrm{R}^{2}$ (R-Square) (0.309), which is mean this model can explains $(30.9 \%)$ of the changes that happened in the variables, in the other words the changes in profitability due to reasons related to the capital structure. And to be more accurate we can use the Adjusted- $\mathrm{R}^{2}$, which is mean the model can explains $26.7 \%$ of changes that happened in profitability due to capital structure.

\subsection{The Main Hypothesis}

H0: There is no significant relationship between the capital structure (DR) and the Financial Performance (ROA, ROE) in the companies listed in the Abu Dhabi Securities Exchange (ADX) for the period (2008-2015). Table 5 below shows the result of ANOVA we can use this table to test the main hypothesis.

Table 5. ANOVA Result

\begin{tabular}{cccccc}
\hline & & \multicolumn{3}{c}{ ANOVA $^{\mathrm{a}}$} \\
\hline Model & & Sum of Squares & Df & Mean Square & F \\
& Regression & 1.124 & 2 & 0.707 & 3.077 \\
1 & Residual & 6.326 & 61 & 0.249 & \\
& Total & 7.440 & 63 & & \\
& & & & & \\
\hline
\end{tabular}

a. Dependent Variable: D.R.

b. Predictors: (Constant), ROA, ROE.

The overall model is statistically significant $(\mathrm{F}=3.07, \mathrm{p}=0.000)$. Furthermore, all of the predictor variables are statistically significant, which means there is significant relationship between the capital structure (DR) and the Financial Performance (ROA, ROE) in the companies listed in the Abu Dhabi Securities Exchange (ADX) for the period (2008-2015). This means accept the Alternative hypotheses and reject the null hypotheses.

\subsection{The 1st Sub-Hypothesis}

H1a: There is significant relationship between the capital structure (DR) and the Financial Performance (ROA) in the companies listed in the Abu Dhabi Securities Exchange (ADX) for the period (2008-2015). Table 6 below shows the result of Coefficients we can use this table to test the 1st sub-hypothesis.

Table 6. Coefficients (DR, ROA)

\begin{tabular}{|c|c|c|c|c|c|c|}
\hline & \multirow{2}{*}{ Model } & \multicolumn{2}{|c|}{ Unstandardized Coefficients } & \multirow{2}{*}{$\frac{\text { Standardized Coefficients }}{\text { Beta }}$} & \multirow{2}{*}{$\mathrm{t}$} & \multirow{2}{*}{ Sig. } \\
\hline & & $\mathrm{B}$ & Std. Error & & & \\
\hline \multirow{2}{*}{1} & (Constant) & -.105 & .108 & & -0.773 & .005 \\
\hline & ROA & 7.548 & 1.550 & .469 & 3.166 & .000 \\
\hline
\end{tabular}

Dependent Variable: D.R.

The relationship between ROA and D.R is positive $(B=7.548)$ and based on the $t$-value=3.166 and $p$-value ( $\mathrm{sig}=0.000)$, we would conclude this relationship is statistically significant. Hence, we would say there is a statistically significant positive linear relationship between ROA and DR. This means there is significant relationship between the capital structure (DR) and the Financial Performance (ROA) in the companies listed in the Abu Dhabi Securities Exchange (ADX) for the period (2008-2015). This means accept the Alternative hypotheses and reject the null hypotheses. 


\subsection{The 2nd Sub-Hypothesis}

H1b: There is significant relationship between the capital structure (DR) and the Financial Performance (ROE) in the companies listed in the Abu Dhabi Securities Exchange (ADX) for the period (2008-2015). Table 7 below shows the result of Coefficients we can use this table to test the 2nd sub-hypothesis.

Table 7. Coefficients (DR, ROE)

\begin{tabular}{|c|c|c|c|c|c|c|}
\hline & \multirow{2}{*}{ Model } & \multicolumn{2}{|c|}{ Unstandardized Coefficients } & \multirow{2}{*}{$\frac{\text { Standardized Coefficients }}{\text { Beta }}$} & \multirow{2}{*}{$\mathrm{t}$} & \multirow{2}{*}{ Sig. } \\
\hline & & B & Std. Error & & & \\
\hline \multirow{2}{*}{1} & (Constant) & -.174 & .128 & & $-1.649-$ & .001 \\
\hline & ROE & -3.001 & 1.226 & .455 & 4.769 & .000 \\
\hline
\end{tabular}

Dependent Variable: D.R.

The relationship between ROE and D.R is Negative $(\mathrm{B}=-3.001)$ and based on the $\mathrm{t}$-value=4.166 and $\mathrm{p}$-value (sig=0.000), we would conclude this relationship is statistically significant. Hence, we would say there is a statistically significant positive linear relationship between ROE and DR. There is significant relationship between the capital structure (DR) and the Financial Performance (ROE) in the companies listed in the Abu Dhabi Securities Exchange (ADX) for the period (2008-2015). This means accept the Alternative hypotheses and reject the null hypotheses.

\section{Conclusion}

The results of this study showed that were consistent with some previous studies, where some of them showed a positive relationship between the capital structure and the Financial Performance, and the others showed negative relationship between the same variables. And as mentioned above in the testing hypotheses there is positive relationship between the capital structure (Debt Ratio) and the Financial Performance (Profitability: Return on Assets) in ADX, and this result consistent with the study of each of Valeriu and Nimalathasan (2010), Magaritis and Psillaki (2010), Baum et al. (2006). In the other hand there is a negative relationship when we used the (Return on Equity) to express for the Profitability and this result consistent with the study of each of Chandrapala and Knapkova (2013), Vatavu (2014), Darush and Peter (2015), Nassar (2016).

Therefore, the researcher recommends the Financial Managers that they accurately analyzed the method of funding to introduce optimal capital structure allowing them to achieve the highest possible profit, and maximizing wealth which is the main goal for all Financial Managers and Owners, the researcher also recommends, to select the appropriate debt ratio in advance that supports the return on equity and return on assets.

\section{Acknowledgements}

Researcher thanks all parties that supported this work, especially Emirates College of Technology, ECT, and Abu Dhabi Securities Exchange ADX for providing all the necessary data.

\section{References}

Campbell, J., \& Luis, V. (2005). The Term Structure of the Risk-Return Tradeoff. National Bureau of Economic Research Working Paper No. 11119. https://doi.org/10.3386/w11119

Chandrapala, P., \& Knapkova, A. (2013). Firm-specific factors and financial performance of firms in the Czech Republic. Acta Universitatis Agriculturae et Silviculturae Mendelianae Brunensis, 7, 2183-2190. https://doi.org/10.11118/actaun201361072183

Chuke, N., Idam O., \& Bamidele, S. U. (2016). The impact of debt structure on firm performance: Empirical evidence from Nigeria quoted firms. Asian Economic and Financial Review, 6(11), 647-660.

Crabtree, A. D., \& DeBusk, G. K. (2008). The effects of adopting the balanced scorecard on shareholder returns. Advances in Accounting, 24(1), 8-15. https://doi.org/10.1016/j.adiac.2008.05.016

Darush, Y., \& Peter, O. (2015). Debt financing and firm performance: An empirical study based on Swedish data. The Journal of Risk Finance, 16(1), 102-118. https://doi.org/10.1108/JRF-06-2014-0085

David, W. M. (1982). Does the Capital Asset Pricing Model Work? Harvard Business Review. 
Dessi, R., \& Robertson, D. (2003). Debt, incentives and performance: Evidence from UK panel data. The Economic Journal, 113(490), 903-919. https://doi.org/10.1111/1468-0297.t01-1-00159

Ebaid, E. (2009). The impact of capital-structure choice on firm performance empirical evidence from Egypt. The Journal of Risk Finance, 10(5), 477-487. https://doi.org/10.1108/15265940911001385

Fattoh, B. (2005). Capital structure in South Korea: A quintile regression approach. Journal of Development Economics, 76, 231-250. https://doi.org/10.1016/j.jdeveco.2003.12.014

French, C. W. (2003). The Treynor Capital Asset Pricing Model. Journal of Investment Management, 1(2), 60-72.

Gibbons, M., Ross, S., \& Shanken, J. (1989, September). A test of the efficiency of a given portfolio. Econometrica, 57(5), 1121-1152. https://doi.org/10.2307/1913625

Goddard, J., Tavakoli, M., \& Wilson, J. (2005). Determinants of profitability in European manufacturing and services: Evidence from a dynamic panel data. Applied Financial Economics, 15(18), 1269-1282. https://doi.org/10.1080/09603100500387139

Graham, J. R., \& Harvey, C. R. (2001). The theory and practice of corporate finance: Evidence from the field. Journal of Financial Economics, 60(2-3), 187-243. https://doi.org/10.1016/S0304-405X(01)00044-7

Iorpev, L., \& Kwanum, I. M. (2012). Capital Structure and Firm Performance: Evidence from Manufacturing Companies in Nigeria. International Journal of Business and Management Tomorrow, 2(5), 1-17.

Ittner, C. D. (2008). Does measuring intangibles for management purposes improve performance?: A review of the $\begin{array}{llll}\text { evidence. Accounting } \& \text { Business } & \text { Research, 38(3), 261-272. }\end{array}$ https://doi.org/10.1080/00014788.2008.9663338

Kebewar, M. (2012). La structure du capital et la profitabilité: Une étude empirique sur données de panel françaises. In MPRA Paper 42446. University Library of Munich.

Margaritis, D., \& Psillaki, M. (2007). Capital Structure and Firm Efficiency. Journal of Business Finance \& Accounting, 34(9-10), 1447-1469. https://doi.org/10.1111/j.1468-5957.2007.02056.x

Modigliani, F., \& Merton, H. M. (1963). Corporate income taxes and the cost of capital: A correction. The American Economic Review, 433-443.

Modigliani, F., \& Miller, M. H. (1958). The cost of capital, corporation finance and the theory of investment. The American Economic Review, 5(3), 261-297.

Nassar, S. (2016). The Impact of Capital Structure on Financial Performance of the Firms: Evidence from Borsa Istanbul. Journal of Business \& Financial Affairs, 5(2), 2016.

Vatavu, S. (2014). The Determinants of Profitability in Companies Listed on the Bucharest Stock Exchange. Annals of the University of Petroşani, Economics, 14(1), 329-338.

Weill, L. (2008). Leverage and Corporate Performance: Does Institutional Environment Matter? Small Business Economics, 30(3), 251-265. https://doi.org/10.1007/s11187-006-9045-7

\section{Copyrights}

Copyright for this article is retained by the author(s), with first publication rights granted to the journal.

This is an open-access article distributed under the terms and conditions of the Creative Commons Attribution license (http://creativecommons.org/licenses/by/4.0/). 